\title{
Suitable and optimal locations for implementing photovoltaic water pumping systems for grassland irrigation in China
}

\author{
P.E. Campana ${ }^{\mathrm{a}, *}$, S. Leduc ${ }^{\mathrm{b}}$, M. Kim ${ }^{\mathrm{c}}$, A. Olsson ${ }^{\mathrm{d}}$, J. Zhang ${ }^{\mathrm{e}}$, J. Liu ${ }^{\text {b,f,g }}$, F. Kraxner ${ }^{\mathrm{b}}$, I. McCallum ${ }^{\mathrm{b}}$, H. Li $^{\mathrm{a}}$, \\ J. Yan ${ }^{\mathrm{a}, \mathrm{d}}$ \\ a School of Business, Society \& Engineering, Mälardalen University, SE-72123 Västerås, Sweden \\ ${ }^{\mathrm{b}}$ International Institute for Applied Systems Analysis (IIASA), A-2361 Laxenburg, Austria \\ ${ }^{c}$ Department of Environmental Science and Ecological Engineering, Korea University, 136-701 Seoul, Republic of Korea \\ ${ }^{\mathrm{d}}$ School of Chemical Science \&' Engineering, KTH Royal Institute of Technology, SE-10044 Stockholm, Sweden \\ ${ }^{\mathrm{e}}$ Department of Geographical Sciences, University of Maryland, MD 20742 College Park, USA \\ ${ }^{\mathrm{f}}$ School of Environmental Science and Engineering, South University of Science and Technology of China, 518055 Shenzhen, China \\ ${ }^{\mathrm{g}}$ School of Nature Conservation, Beijing Forestry University, 100083 Beijing, China
}

\section{H I G H L I G H T S}

- A new approach to assess the grassland sites for PVWP irrigation systems is proposed.

- A spatial explicit optimization model is used to assess the optimal locations.

- The potentials of PVWP systems for grassland conservation are substantial.

- The potential of PVWP in carbon emissions reduction is significant.

\section{A R T I C L E I N F O}

\section{Article history:}

Received 15 September 2015

Received in revised form 25 December 2015

Accepted 2 January 2016

Available online $\mathrm{xxxx}$

\section{Keywords:}

Photovoltaic water pumping

Grassland

Irrigation

Optimization

Spatial analysis

\begin{abstract}
A B S T R A C T
Grassland plays a key role for the food security of China because of the large number of livestock raised in those areas. Thus, grassland degradation due to climate change and overgrazing is considered as one of the most severe environmental and economic threat for the future sustainable development of China. Photovoltaic water pumping systems for irrigation can play a fundamental role for the conservation of grassland areas.

This paper investigates the geospatial distribution of the technically suitable grassland locations for the implementation of photovoltaic water pumping systems. The technically suitable grassland areas were taken as starting point to assess the optimal locations. The assessment of the optimal locations was conducted using a spatially explicit optimization model of renewable energy systems based on the cost minimization of the whole forage supply chain.

The results indicate that the photovoltaic water pumping systems provide high potential for improving forage productivity, contributing to meet the local demand. The optimal areas are highly sensitive to several environmental and economic parameters such as increased forage potential yield, forage management costs, forage water requirements, ground water depth, forage price and $\mathrm{CO}_{2}$ price. Most of the optimal areas are selected when the market forage price ranges from 300 to $500 \$ /$ tonne DM, indicating that the forage produced using PVWP technology for irrigation is already competitive compared to the imported forage.
\end{abstract}

(c) 2016 Elsevier Ltd. All rights reserved.

\section{Introduction}

In China, grassland covers nearly 4 million $\mathrm{km}^{2}$, accounting for more than $40 \%$ of the national land surface. Furthermore, grassland

\footnotetext{
* Corresponding author.
}

plays a key role in achieving sustainable development and enhancing food security of the country since 100 million livestock are raised in those areas [1]. In recent years, photovoltaic water pumping (PVWP) technology for grassland and farmland conservation was successfully implemented in different pilot sites in China: Qinghai [2,3], Inner Mongolia [4] and Xinjiang [5]. The combination of PVWP technology with water saving irrigation techniques and 
sustainable water management showed that it is technically feasible to improve grassland productivity in areas without access to the grid. The grassland productivity can be increased up to 20-30 times using PVWP systems for irrigation, without imposing a severe threat to the available water resources [2]. Moreover, PVWP systems are an economically suitable technology to provide electricity for irrigation both in off- and on-grid areas, also avoiding a further pressure on the energy requirements in the pastoral-farming sector [6].

Identification of feasible locations were studied for the implementation of PVWP technology for grassland and farmland conservation in China [2,3]. In these studies, the feasible grassland areas for implementing PVWP irrigation technology were evaluated through the combination of a set of spatial data on land cover and slope, precipitation, temperature and sunshine hours. The spatial data regarding the land cover and terrain slope were considered to assess the suitable grassland areas for the installation of irrigation systems. According to previous recommendation, the slope must be lower than $2-5 \%$ for furrow irrigation and lower than 5$9 \%$ for micro-spray irrigation to avoid runoff, soil erosion, and water and energy wastage $[2,3]$. The suitable annual precipitation for PVWP irrigation systems was between 300 and $600 \mathrm{~mm}$ on the basis of grassland water demand [2,3]. The suitable annual ambient temperature and sunshine hours should be lower than $20^{\circ} \mathrm{C}$ and greater than $1400 \mathrm{~h}$, respectively [2,3]. The constraint of the annual ambient temperature was related to the effect of temperature on the evapotranspiration and thus on the grassland water demand. The temperature constraint was also set to avoid an excessive decline of the PV modules working efficiency. However, the constraint of the annual sunshine hours was an indirect measure of the solar energy resources required to drive the PVWP systems. System optimization was carried out considering the incremental benefit of irrigation, assessing the rate of the investment return in relation with the precipitation. The authors concluded that the highest economic benefits of PVWP systems could be achieved in areas marked out by $350-400 \mathrm{~mm}$ of precipitation [2,3].

Nevertheless, an in-depth analysis considering the detailed availability of water resources in identifying the technically suitable grassland and farmland areas for implementing PVWP systems was not addressed in the previous studies [2,3]. Moreover, the costs related to the supply chain and the co-benefits of implementing PVWP systems for grassland and farmland conservation were not thoroughly considered in the conducted optimization [3].

The aim of this paper is to identify the most technically suitable grassland areas for implementing PVWP technology for forage irrigation, taking into account the availability of water resources in the assessment. A more comprehensive approach for identifying the areas that require irrigation was also adopted. Once identified, these areas were subject to the selection of the optimal locations for installing PVWP systems, using an optimization model that minimizes the supply chain costs of forage production. The cobenefits of implementing PVWP systems for irrigation, such as $\mathrm{CO}_{2}$ emission reductions and carbon sequestration, were also included in the optimization model. Another contribution of this work is that the forage supply chain in China using PVWP technology as mean to provide water for irrigation was studied for the first time. The results provide a better understanding on how PVWP technology can be a solution for the sustainable development of the pastoral and irrigation sectors in China.

This paper is organized as follows: Section 2 provides a general overview of the methodology applied in this work to assess the suitable and optimal grassland areas for implementing PVWP irrigation systems. The corresponding subsections address the methodologies applied in details; in Section 3, the results of the spatial assessment and optimization are presented and discussed; Section 4 summarizes the outcomes of this study pointing out the directions for future works.

\section{Methodology}

The conceptual framework applied in this study to identify the suitable and optimal grassland areas for the implementation of PVWP systems for irrigation is depicted in Fig. 1. The methodology is divided into two main parts: the first is the spatial analysis, focusing on the assessment of the technically suitable areas and on the primary spatial input data used for selecting the optimal locations in the optimization tool (such as PVWP system capacity, increased forage yield due to irrigation, forage demand, and transportation distances); the second part deals with identifying the optimal locations among the technically suitable locations using BeWhere model [7-10].

The suitable grassland areas were assessed using the following spatial data: grassland distribution, terrain slope, precipitation, potential evapotranspiration, and water stress index (WSI). The approach used in this study to assesses the suitable areas for implementing PVWP irrigation systems, hereafter called "Approach 2", was compared to a previous approach developed by Yan et al. [2] and Yu et al. [3], hereafter called "Approach 1". A detailed description of Approaches 1 and 2 is given in Section 2.1. The suitable grassland locations represent the main spatial input data for the optimization model and the optimal locations were selected among the suitable ones during the optimization process.

The spatial distribution of the PVWP system capacity was calculated using the spatial data of solar irradiation, groundwater depth, and irrigation water requirement (IWR) which is related to the reference evapotranspiration $E T_{o}$. Solar irradiation, groundwater depth, and IWR represent the main design parameters for PVWP irrigation systems assuming groundwater as the water source. The PVWP system design map was used to calculate the spatial distribution of the PVWP initial capital costs (ICC).

To estimate the effect of irrigation on the forage yield, the spatial data about IWR was used along with an experimental relationship between annual average irrigation and NPP increase. The increased forage yield is the main economic benefit produced by the implementation of PVWP irrigation systems, thus representing one of the main spatial input data for the optimization model.

The forage demand was assessed using the spatial data of livestock density, taking into account the average forage intake of small and big ruminants.

The road and rail networks were utilized to assess the transportation distances between grassland forage supply locations and livestock forage demand locations. Accordingly, the transportation distances are fundamental to assess the transportation costs and emissions.

The spatial data, together with techno-economic parameters (i.e. PVWP system specific ICC, forage management costs, market forage price, road and railway specific transportation costs, electricity price, incentives for renewable power generation, and $\mathrm{CO}_{2}$ offsets) were used as the input data to identify the optimal location using the BeWhere model. This model was originally developed to determine the optimal locations of bioenergy production facilities, such as biomass CHP plants or biogas plants. In this work, the original version of BeWhere was adjusted to identify the optimal PVWP system locations for forage production.

\subsection{Feasible grassland areas}

In this article, the analysis of the technically suitable grassland areas for the implementation of PVWP systems was conducted using GIS-supported spatial analysis including some relevant differences as compared to "Approach 1" [2,3]. The following spatial data were taken into account: grassland distribution, terrain slope, precipitation, potential evapotranspiration and WSI. The grassland 


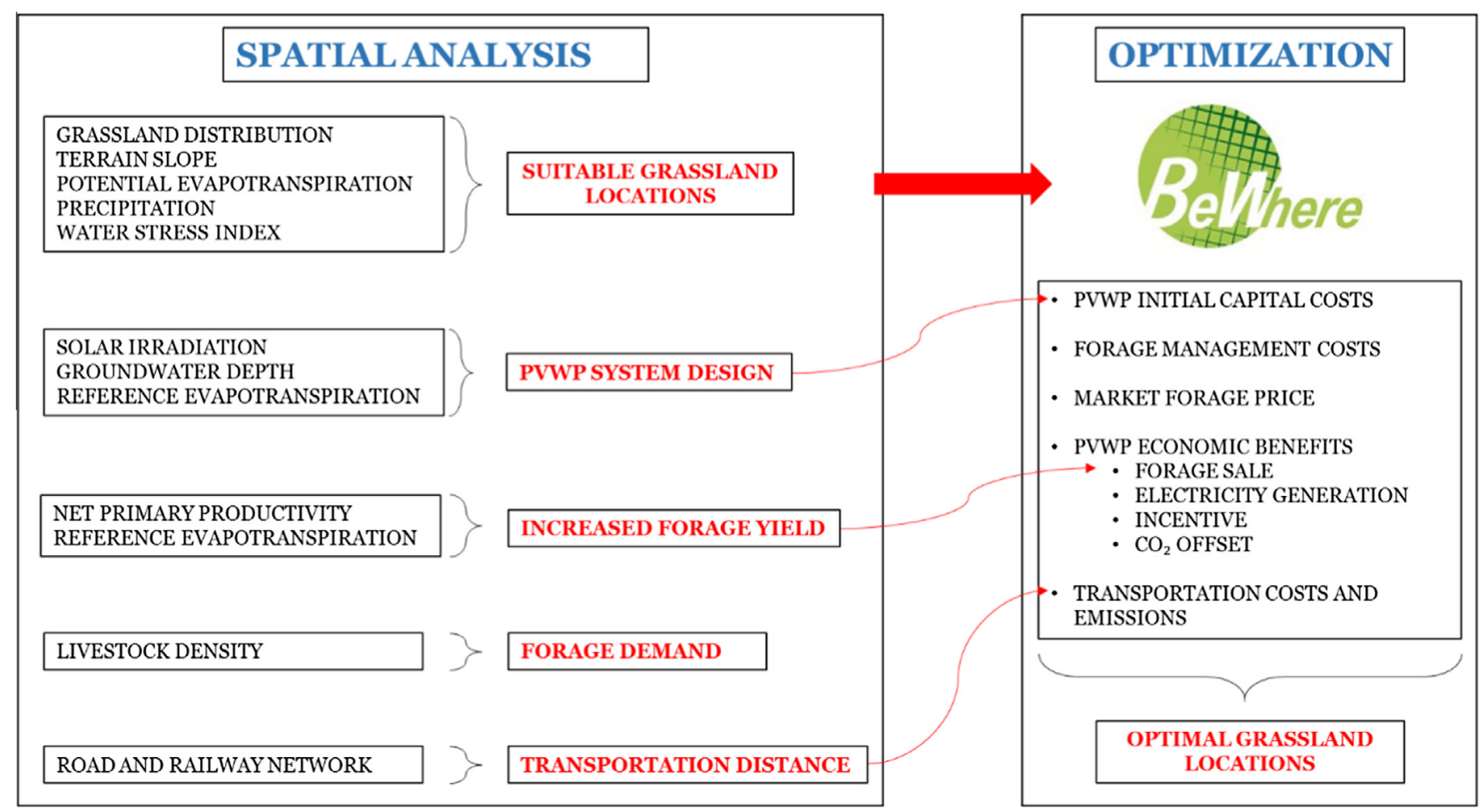

Fig. 1. Conceptual framework to assess the suitable and optimal grassland locations for implementing PVWP systems for irrigation.

distribution dataset $\left(30^{\prime \prime}\right.$ spatial resolution $\approx 1 \mathrm{~km} \times 1 \mathrm{~km}$ at the equator) was derived from the GLC2000 grid data available in DIVA-GIS [11]. The spatial distribution of the terrain slope was calculated from the CGIAR-SRTM elevation data (30" spatial resolution $\approx 1 \mathrm{~km} \times 1 \mathrm{~km}$ at the equator) available in DIVA-GIS [11]. The raster data of precipitation (as well as the raster data of temperature) was taken from the WordClim dataset (30" spatial resolution $\approx 1 \mathrm{~km} \times 1 \mathrm{~km}$ at the equator) [12]. The precipitation spatial data were generated through interpolation of average monthly climate data gathered from weather stations at $1 \mathrm{~km}$ resolution [13]. The potential evapotranspiration dataset $\left(30^{\prime \prime}\right.$ spatial resolution $\approx 1 \mathrm{~km} \times 1 \mathrm{~km}$ at the equator) was taken from CGIAR-CSI [14]. The WSI spatial distribution $\left(30^{\prime}\right.$ spatial resolution $\approx 50 \mathrm{~km} \times 50 \mathrm{~km}$ at the Equator) was taken from Vörösmarty et al. [15].

Similarly to "Approach 1", grassland distribution and slope of terrain were used to identify the technically suitable grassland areas for the installation of irrigation systems. However, the installation of micro-irrigation systems should be avoided when the terrain slope is higher than $9^{\circ}$ due to water erosion and accordingly waste of water [3]. Differently from the previous assessments, the areas where irrigation is required were estimated considering the difference between precipitation and potential evapotranspiration (a difference lower than 0 means that irrigation is required). As compared to the "Approach 1", the method used in this work to identify the grassland areas that require irrigation represents a more general approach. Moreover, the spatial distribution of the WSI, defined as the ratio of water demand to sustainable water resources, was used to remove those areas marked out by a high water stress in the suitability analysis [15]. Thus, in identifying the technically suitable locations for PVWP irrigation technology, only the areas marked by a low (WSI $<0.1$ ), moderate to low (WSI $<0.2$ ), and medium-high to low (WSI < 0.4) WSI were taken into account to provide the most conservative results. This assumption was taken based on the fact that water security is one of the main environmental and economic threats for China.
The spatial data regarding the sunshine duration was derived from the punctual sunshine duration data of 80 Chinese weather stations available in the global meteorological database Meteonorm using the GIS Kriging interpolation [16].

Table 1 shows the spatial data taken into account to identify the technically suitable areas for implementing PVWP systems for grassland conservation, both for "Approach 1" and "Approach 2".

Different from Approach 1, the constraint of temperature and sunshine duration was not considered due to the following reasons: (a) the temperature constraint was set to consider the negative effects of temperature on evapotranspiration and PV modules efficiency. Nevertheless, this constraint does not provide any clear information regarding the grassland areas suitability. On the other hand, it gives an indirect information about the effects of temperature on the crop water requirements and consequently on the PVWP system overall efficiency. Those effects are more tightly related to the PVWP irrigation system design and optimization. In this study, the spatial effects of evapotranspiration and thus crop water requirements, and the PV module temperaturedependent efficiency were taken into account in the optimization

Table 1

Spatial data used for the assessment of technically suitable grassland areas for PVWP irrigation systems.

\begin{tabular}{lll}
\hline Definition & Approach 1 [2,3] & Approach 2 \\
\hline Grassland area & $\begin{array}{l}\text { Grassland } \\
\text { distribution [11] }\end{array}$ & Grassland distribution [11] \\
$\begin{array}{c}\text { Area suitable for } \\
\text { irrigation }\end{array}$ & $\begin{array}{l}\text { Terrain slope }\left(<9^{\circ}\right) \\
{[11]}\end{array}$ & Terrain slope $\left(<9^{\circ}\right)[11]$ \\
$\begin{array}{c}\text { Area where } \\
\text { irrigation is } \\
\text { required }\end{array}$ & $\begin{array}{l}\text { Precipitation }(300- \\
\text { Constraint }\end{array}$ & $\begin{array}{l}\text { Precipitation [12] - Potential } \\
\text { evapotranspiration }[14](<0)\end{array}$ \\
& $\begin{array}{l}\text { Temperature } \\
\left(<20^{\circ} \mathrm{C}\right)[12]\end{array}$ & Water stress index [15] \\
& $\begin{array}{l}\text { Sunshine duration } \\
(>1400 \mathrm{~h} / \text { year })[16]\end{array}$ & \\
\hline
\end{tabular}


phase; (b) the sunshine duration constraint was set to identify the suitable areas under a solar potential viewpoint. However, using the sunshine duration does not give any information regarding the solar irradiation potential that can affect the PVWP irrigation system operation. Similarly, the distribution of the sunshine duration does not provide any straightforward information on the grassland areas suitability. Since the solar irradiation affects the PVWP irrigation system capacity, in this study it was considered in the optimization process as a parameter affecting the PVWP system ICC.

\subsection{Optimal locations}

The assessment of the feasible grassland areas for the implementation of PVWP irrigation systems was a starting point for the search of the optimal areas. The optimal locations for PVWP units were estimated using BeWhere, an optimization model for renewable energy systems developed at the International Institute for Applied Systems Analysis (IIASA) [7-10]. BeWhere is a mixed linear integer program written in GAMS ${ }^{\circledR}$ that minimizes the costs of the entire supply chain, including feedstock harvest, transportation, conversion and delivery of final energy products. For the specific purpose of identifying the optimal areas for PVWP irrigation systems, the original version of BeWhere was adapted in order to minimize the supply chain costs for forage production in China, considering the technically suitable grassland areas as the supply locations. The BeWhere model minimizes the costs of the entire forage production chain, including the PVWP system installation costs, forage management costs, transportation costs and additional forage costs, to meet the forage demand. When minimizing the supply chain costs, the following revenues were also taken into consideration: revenues due to PVWP system electricity surplus sales as well as carbon offset credits. Indeed, the implementation of PVWP systems lead to a substantial reduction of $\mathrm{CO}_{2}$ emissions due to the surplus of PV power production during the non-irrigation period, and carbon sequestration through restoration of degraded grasslands [6,17]. The negative effects of $\mathrm{CO}_{2}$ emissions due to forage transportation were also taken into account. An extensive and detailed description of the mathematical model of BeWhere can be found in Leduc et al. [10] and in Wetterlund et al. [18].

Three different scenarios were considered: (1) business as usual (BAU) (forage sale is the only income connected to the PVWP system operation); (2) BAU + electricity + incentives (the surplus of electricity and the corresponding incentives for renewable power production in China are considered as part of the revenues of the base case); and (3) $\mathrm{BAU}+$ carbon trading (the $\mathrm{CO}_{2}$ emission reductions and carbon sequestration are considered as offsets at $50 \$ /$ tonne $\mathrm{CO}_{2}$ ).

\subsubsection{PV water pumping system design and costs}

This section describes the approach used to calculate the spatial distribution of the PVWP system capacity and costs, and the related spatial data used in the calculations. The main parameters required to design PVWP systems for irrigation are: the monthly average daily peak of IWR, the operational hydraulic head $H_{o}$, and the monthly average daily solar irradiation hitting the PV array $E_{s}$. The IWR was calculated from the reference evapotranspiration $E T_{o}$ and precipitation spatial data assuming June as the design month (month marked out by the highest ratio between IWR and solar irradiation hitting the PV array) [19]. The $E T_{o}$ spatial data ( $10^{\prime}$ spatial resolution $\approx 20 \mathrm{~km} \times 20 \mathrm{~km}$ at the Equator) was taken from the FAO GeoNetwork database [20]. The dataset contains mean monthly values for global land areas, excluding Antarctica, for the period 1961-1990. The dataset was produced based on the FAO Penman-Monteith method with limited climatic data as described in FAO Irrigation and Drainage Paper 56 [21]. In particular, the IWR $\left(\mathrm{m}^{3} / \mathrm{ha} /\right.$ day $)$ was computed using the FAO guidelines taking into account the efficiency of the irrigation systems and the leaching requirements [21,22]. The following equation summarizes the approach used to calculate IWR:

$I W R=\frac{E T_{o} K_{c}-P_{e}}{\eta_{\text {irr }}(1-L R)}$

where $K_{c}$ is the cultural coefficient dependent on crop growth stage; $P_{e}$ is the monthly average daily effective precipitation, calculated as $80 \%$ of total precipitation [23]; $\eta_{\text {irr }}$ is the efficiency of the irrigation systems assumed to be equal to $80 \%$ [23]; LR is the leaching requirement needed to remove residual salts from the root zone. To avoid soil salinity issues from irrigation, an $18 \%$ leaching requirement was taken into account [24]. In the specific case, Alfalfa (Medicago Sativa) was used as reference crop as it is one of the most widely used forage crop. All the calculation are based on 1 ha irrigated field, successively scaled up for the whole investigated areas.

The operational hydraulic head $H_{o}(\mathrm{~m})$ was calculated from the groundwater depth spatial data taking into account a surplus of hydraulic head equal to $20 \mathrm{~m}$ to guarantee the correct functioning of a 1 ha micro irrigation system [25]. The groundwater depth dataset was taken from the Global Water Scarcity Information Service (GLOWASIS) [26,27]. The dataset contains model simulated equilibrium water table depth ( $\mathrm{m}$ below land surface) on a global scale ( $15^{\prime}$ spatial resolution $\approx 25 \mathrm{~km} \times 25 \mathrm{~km}$ at the Equator).

The solar irradiation GIS data $\left(24^{\prime}\right.$ spatial resolution $\approx 40 \mathrm{~km} \times 40 \mathrm{~km}$ at the Equator) was taken from Open Energy Information database [28]. The data provides the spatial distribution of the solar irradiation hitting a surface market out by an azimuth angle equal to $0^{\circ}$ and a tilt angle equal to the latitude of the location. This assumption allows the maximization of the annual solar irradiation harvested by the PV array [29].

The PVWP system power peak $\left(P_{P, P V P W}\right)\left(\mathrm{kW}_{\mathrm{p}}\right)$ was calculated using the following equation:

$P_{P, P V W P}=\frac{E_{h}}{f_{m}\left[1-\alpha_{c}\left(T_{c e l l}-T_{0}\right)\right] \eta_{p} E_{s}}$

where $E_{h}$ is the monthly average daily hydraulic energy ( $\mathrm{kWh}$ h/day) required to lift up the IWR ( $\mathrm{m}^{3} / \mathrm{ha} /$ day) against an hydraulic head equal to $H_{o}(\mathrm{~m}) ; f_{m}$ is the matching factor assumed equal to 0.9 as found in Khatib [30]; $\alpha_{C}$ is the PV module temperature coefficient equal to $0.45 \% /{ }^{\circ} \mathrm{C}$ as found in Skoplaki and Palyvos [31]; $T_{\text {cell }}$ is the cell temperature depending on the ambient temperature $\left({ }^{\circ} \mathrm{C}\right)$; $T_{0}$ is the reference temperature equal to $25^{\circ} \mathrm{C} ; \eta_{p}$ is the efficiency of the pump; and $E_{s}$ is the monthly average daily solar irradiation hitting the PV array $\left(\mathrm{kW} \mathrm{h} / \mathrm{m}^{2} /\right.$ day $)$. The daily hydraulic energy $E_{h}$ was calculated with the following equation:

$E_{h}=\rho g H_{0} I W R$

where $\rho$ is the water density $\left(1000 \mathrm{~kg} / \mathrm{m}^{3}\right)$, and $g$ is the gravity acceleration $\left(9.8 \mathrm{~m} / \mathrm{s}^{2}\right)$. The simplified approach in use was validated through dynamic simulations of PVWP systems in Campana et al. [22]. The resulting spatial distribution of PVWP system capacity for irrigating Alfalfa in Qinghai Province is shown in Fig. 2. The design maps for PVWP irrigation systems can be adopted as a basis for the optimal planning of PVWP system spread, providing a handy tool for policy makers, farmers, investors and consultants interested in solar pumping applications.

The spatial ICC of the PVWP systems was then calculated from the spatial distribution of PVWP system capacity, taking into consideration of the specific costs of the PVWP systems according to the data provided by a Chinese PVWP manufacturer company [32]. The data is depicted in Fig. 3. The PV module price was assumed equal to $1 \$ / \mathrm{W}_{\mathrm{p}}$. The specific inverter and pump costs were assumed equal to 0.5 and $0.15 \$ / \mathrm{W}$, respectively [32]. The 


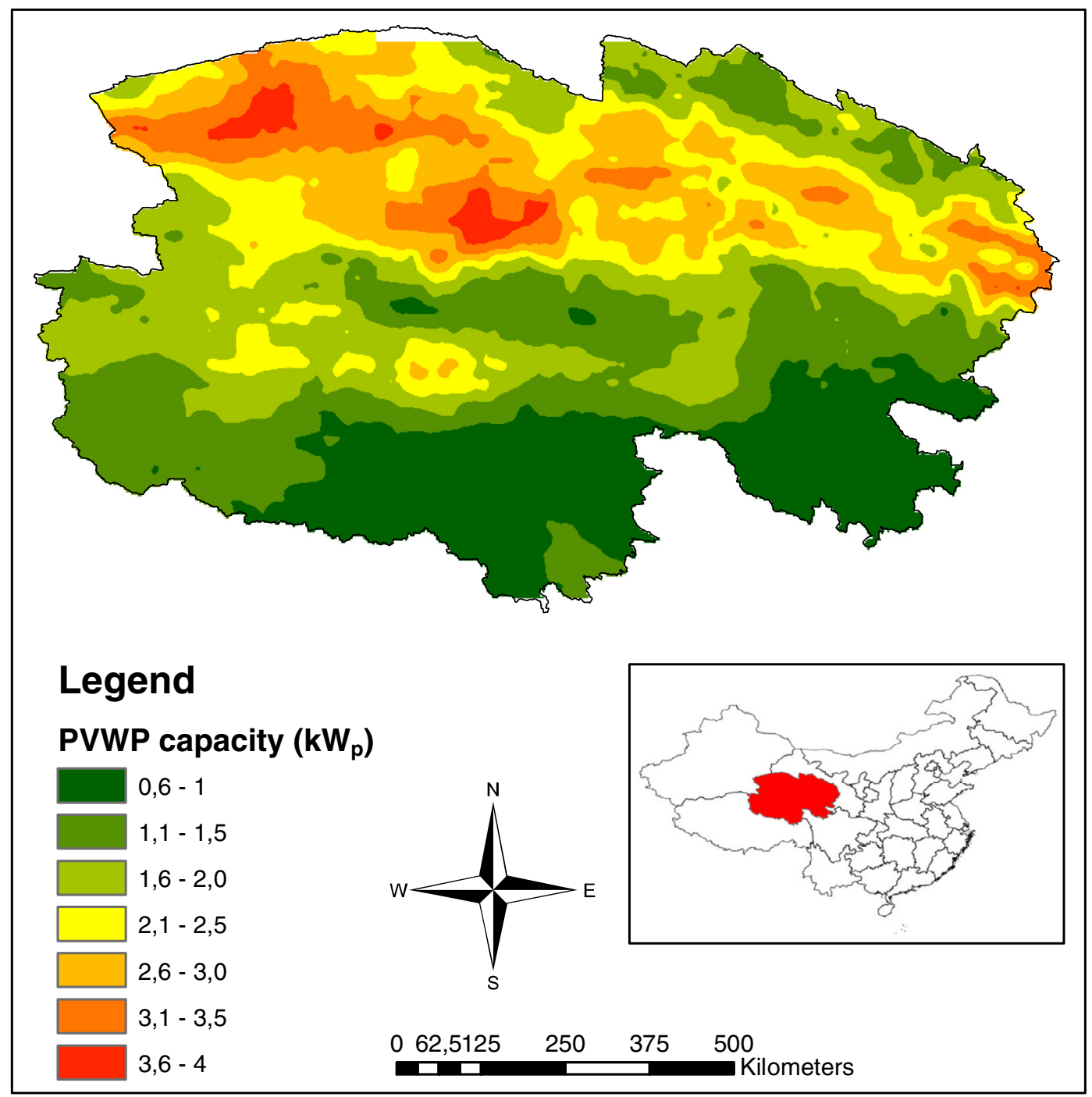

Fig. 2. PVWP system design map for the irrigation of 1 ha Alfalfa in Qinghai Province, China.

project implementation costs were set equal to $30 \%$ of the PVWP components cost, including the cost for design and installation [32].

2.2.1.1. PVWP surplus electricity production and $\mathrm{CO}_{2}$ emission reductions. The common design approach of PVWP systems for irrigation sizes the PV array for the month that has the highest ratio of

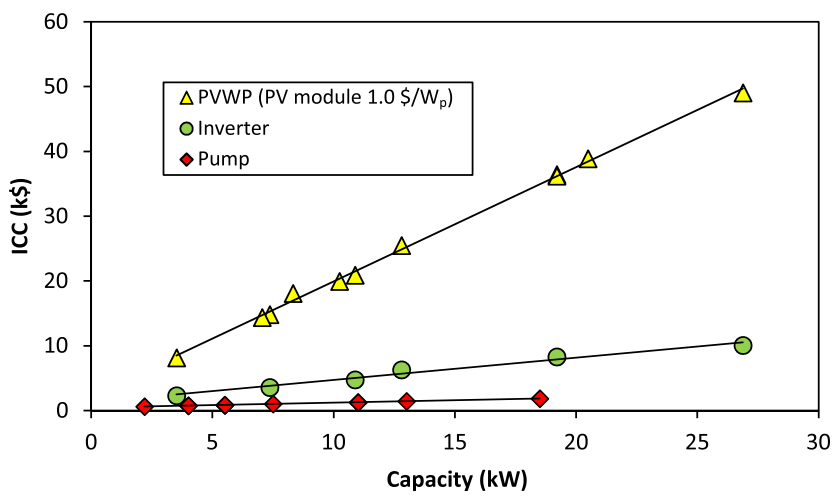

Fig. 3. PVWP system initial capital costs (ICC) as a function of the installed capacity [31].
IWR to $E_{s}[19]$. This design procedure has the disadvantage of making the PVWP system oversized for most of the irrigation season due to the variability of IWR, and unused during the nonirrigation season. As previously addressed in Campana et al. [33], the surplus of electricity production by PVWP systems can be injected to available electric grid or used for other electric loads. The annual surplus of electricity production $E_{\text {sur }}$ can be calculated with the following equation modified from Duffie and Beckman [34]:

$E_{\text {sur }}=\eta_{P V} A_{P V} E_{s, g l o b}(1-I F)$

where $\eta_{P V}$ is the efficiency of the PV module, assumed equal to 14 (\%); $A_{P V}$ is the PV array area $\left(\mathrm{m}^{2}\right)$, which depends on the installed $\mathrm{PV}$ peak power; $E_{s, \text { glob }}\left(\mathrm{kW} \mathrm{h} / \mathrm{m}^{2} /\right.$ year $)$ is the annual global solar irradiation on the PV array area; and IF is the irrigation factor. IF is a measure of the energy used for irrigation purposes compared to the total energy produced by the PV array. IF was set equal to $30 \%$ based on the results achieved in previous works conducted in different locations in China [6,19,22,33]. If the PVWP system is installed nearby the electric grid, as shown in Fig. 4, the surplus of electricity production is eligible to benefit from the available incentives for renewable energy generation.

Thus, the revenues generated by $E_{\text {sur }}$ were calculated considering the current feed-in tariffs available in China for distributed PV 


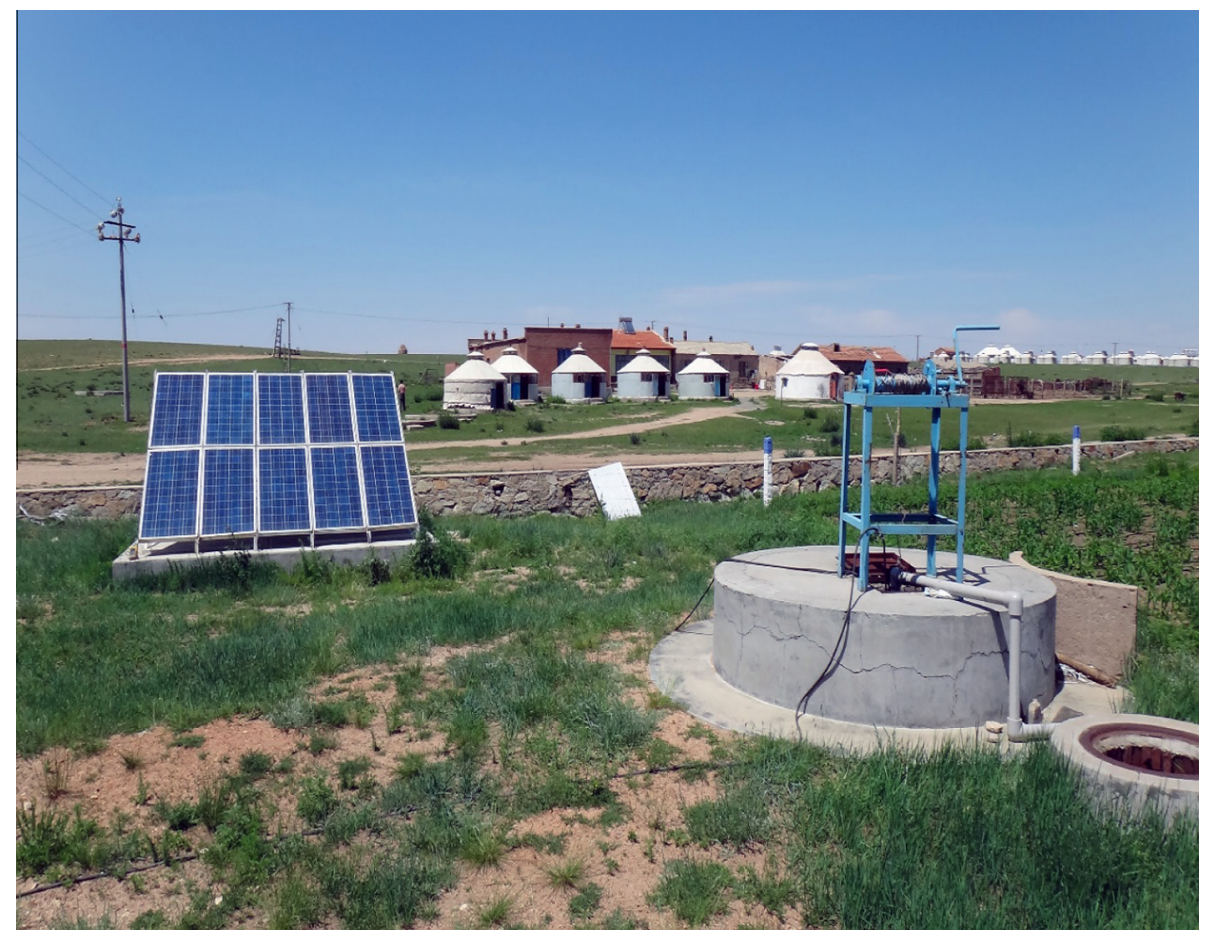

Fig. 4. PVWP system for irrigation installed in Xilamuren, Inner Mongolia (the PV array is installed nearby the available electric grid).

power generation, equal to $0.07 \$ / \mathrm{kWh}(0.42 \mathrm{CNY} / \mathrm{kWh})$ [35]. Moreover, the surplus of electricity production can provide benefit for carbon offsets, as discussed in Campana et al. [6] and Olsson et al. $[17,36]$. The emission reductions achieved by the PV system was calculated using the combined margin approach developed for use in the Clean Development Mechanism [37] with data based on the Chinese authorities [38]. The value for the North West grid, including Qinghai region, was used due to the fact that the largest feasible area for PVWP systems is located in that region. The value is $831 \mathrm{gCO}_{2} / \mathrm{kW} \mathrm{h}$. To conduct a sensitivity analysis, the carbon offsets were assumed equal to 25,50 and $75 \$ /$ tonne $\mathrm{CO}_{2}$ [8].

\subsubsection{Forage yield, management costs, and carbon sequestration}

To study the effect of irrigation on the NPP and consequently on the Alfalfa yield, the experimental relationship between annual average irrigation and NPP increase, proposed by Ozdogan [39] and depicted in Fig. 5, was used. The average irrigation was computed from the spatial data of reference evapotranspiration and precipitation applying the procedure described in Section 2.2.1.

Using the approach described in Vadrevu and Lasko [40] and Qin et al. [41], the Alfalfa economic yield (EY) was derived from the NPP through the following equation:

$E Y=\frac{N P P H I}{D C(R S-1)}$

where $H I$ is the harvest index; $D$ is the dry proportion of the $E Y ; C$ is the carbon content in the dry matter; $R S$ is the root shoot ratio. $H I$, $D, C$, and $R S$ were assumed equal to $1,0.85,0.5$, and 0.87 , respectively [42].

The forage management costs, including soil preparation, sowing, seed, fertilizer, pesticide, irrigation and harvest/bailing machinery costs were set equal to 1000 \$/ha/year [43].

PVWP irrigation systems can be used to restore degraded grasslands that have lost a substantial part of soil organic carbon. Providing sufficient water for biomass growth and excluding the grassland areas from overgrazing can sequester the carbon from the atmosphere back to the soil. To estimate the carbon sequestra-

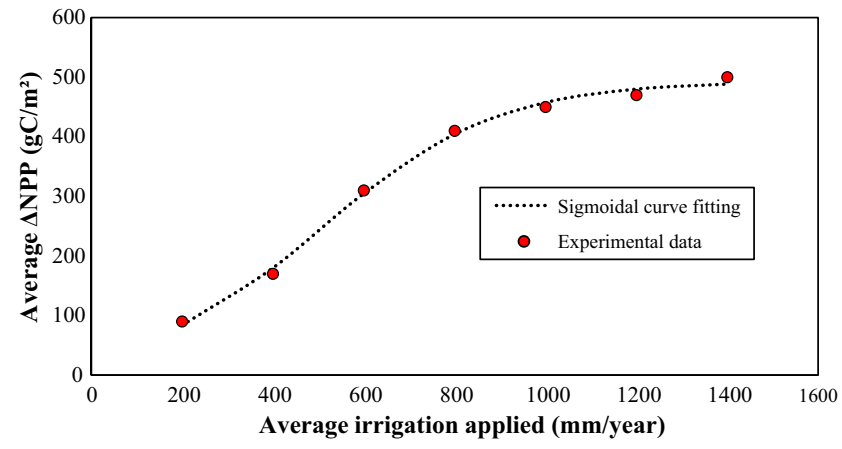

Fig. 5. Experimental relationship between annual average irrigation and NPP increase ( $\triangle \mathrm{NPP})[39]$.

tion due to grassland restoration, we used the default values given by the IPCC [44]. The following assumptions were set: (a) the feasible areas are dominated by the IPCC default soil class high activity clay [45], and $11 \%$ of the areas are severely degraded, $11 \%$ are moderately degraded, and the rest are only slightly degraded or non-degraded [46]; (b) the leakage from increased $\mathrm{N}_{2} \mathrm{O}$ emissions as calculated by Olsson et al. [17]. These assumptions give an average value of 1.03 tonne $\mathrm{CO}_{2} /$ ha/year during 20 years, after which sequestration no longer takes place.

\subsubsection{Forage demand}

China's forage demand was assessed from the 2005 FAO spatial data about predicted livestock density (number of livestock for $\mathrm{km}^{2}$ ) (3' spatial resolution $\approx 5 \mathrm{~km} \times 5 \mathrm{~km}$ at the equator) [47]. The spatial data has a resolution of 0.05 degree. Four livestock species were taken into consideration in the forage demand assessment: cattle, buffaloes, goats, and sheep. The forage demand was calculated assuming an average fodder intake differentiated between small and big ruminants: 2 and $7 \mathrm{~kg} \mathrm{DM}$ (dry matter)/day, respectively $[48,49]$. 


\subsubsection{Transportation}

The roads and rails network was used to calculate the transportation routes between forage production locations and forage demand locations. The transportation network model was developed using the roads and rails dataset available in DIVA-GIS [11]. The transportation routes were calculated using the GIS function "Network Analyst". Accordingly, the transportation routes were used to calculate the corresponding transportation distances, costs and $\mathrm{CO}_{2}$ emissions. A detailed description of the transportation model used in BeWhere can be found in Leduc et al. [9]. The means of the two transportation distances for forage were taken into account: truck and train. The corresponding specific transportation costs for trucks and trains are given in Fig. 6. The transportation costs refer to biomass transportation costs as provided by Sokhansanj et al. [50]. The specific $\mathrm{CO}_{2}$ emissions from trucks and rails were set equal to 62 and $22 \mathrm{gCO}_{2} /$ tonne-km [51], respectively. The overall $\mathrm{CO}_{2}$ emissions due to transportation are based on the tonne-km by transportation mode assuming that the transported forage mass is the only surplus compared to the local demand.

\section{Results and discussions}

\subsection{Suitable areas}

The comparison between the calculated suitable areas identified using Approach 1 and Approach 2 as a function of the WSI is depicted in Fig. 7 in the form of a disagreement map. The total suitable grassland areas for the implementation of PVWP irrigation systems as a percentage of the total grassland area in China is also shown in Fig. 7 as a function of the used approach and WSI. The common areas of both approaches are also highlighted. Comparing Approach 1 with Approach 2 (WSI $<0.1$ ), despite the total technically suitable area is almost similar (around 15\% of the total grassland area), there is a significant disagreement in the spatial distribution, especially with respect to the central provinces of China. Based on Approach 1, the technically suitable areas for grassland irrigation in China are mainly located within a zone from the northeast to the southwest of China. On the contrary, the technically suitable areas using Approach 2 (WSI $<0.1$ ) are located in the northeast of China, in particular in the northeast part of Inner Mongolia, as well as in the southwest of China, mainly in Qinghai, Sichuan and Tibet. This significant difference is mainly due to the WSI not considered by Approach 1 . Taking into consideration a moderate to low WSI (WSI $<0.2$ ), and a medium-high to low WSI (WSI <0.4), the suitable grassland areas for implementing PVWP irrigation technology increase up to $20 \%$ and $26 \%$, respectively. In particular, considering a medium-high to low WSI, scattered areas located in the North part of Xinjiang, North part of

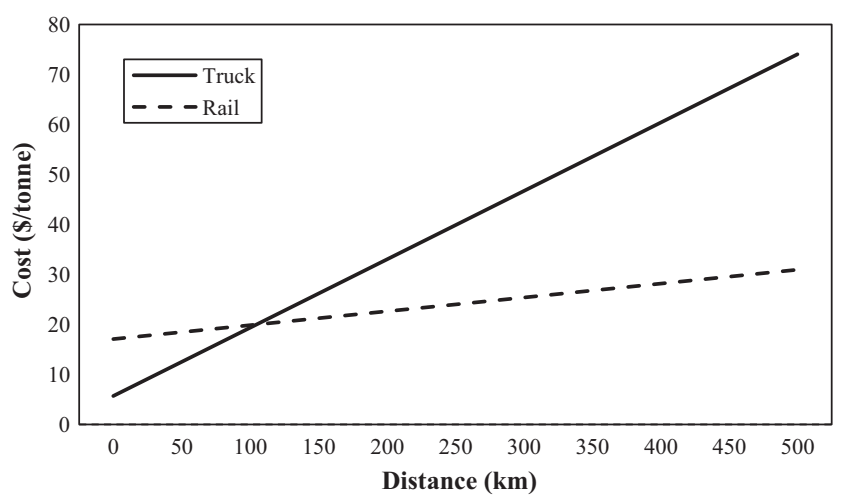

Fig. 6. Transportation costs [50].
Inner Mongolia, central Provinces of China (Gansu, Shaanxi, Henan, Hubei), and central areas of Tibet become suitable areas for solar irrigation.

Considering the areas identified by Approach 2 (WSI $<0.1$ ), the calculated potential increased forage production is 2.6 Mtonne DM for the entire country, corresponding to about $0.75 \%$ of the calculated total livestock fodder demand in China (the calculated total livestock fodder demand in China is about $10 \%$ higher than the forage demand calculated by Herrero et al. [52]). At the same time, this potential is about thirty times higher than the Chinese 2013 Alfalfa import amount, equal to 0.1 Mtonne DM [53]. The results show how PVWP systems represent a renewable energy-based solution to support the sustainable development of the pastoral sector in China. Moreover, the potentials of PVWP systems for grassland conservation and increasing its productivity are significant and strategic for China.

\subsection{Optimal areas}

The results of the optimization process carried out with the BeWhere model in terms of increased forage production as a function of the forage market price to meet the forage local demand are depicted in Fig. 8. BeWhere starts to select the optimal locations, and thus takes into account the corresponding potential forage production, when the PVWP forage cost is competitive with the market forage price required to fulfill the local demand. By increasing the market forage price, the number of locations selected increases as well as the PVWP forage production. Most of the locations are selected when the forage price ranges from 300 to $500 \$ /$ tonne DM. The results indicate that the forage produced using PVWP irrigation technology is already competitive compared to the imported price. The price of Alfalfa imports varied from 200 to $400 \$$ /tonne DM between 2009 and 2013 [53] with the United States as the major exporter. It is interesting to highlight that the imported prices are also likely to increase due to the high Alfalfa water requirements and the drought periods that were affected United States during the past years [54].

Furthermore, the results show that grassland irrigation can play a key role in the sustainable future of China and at the same time for enhancing the rural economies. Grassland irrigation can increase the internal forage supply to meet the internal demand for livestock or at least substantially reduce the forage imports. The surplus of electricity sale and incentives have a marginal impact in the search of the optimal locations. Similarly, the offsets generated by carbon trading slightly increase the competitiveness of PVWP systems for forage irrigation even if at high carbon offsets $\left(50 \$\right.$ /tonne $\mathrm{CO}_{2}$ ). Nevertheless, the carbon offsets make PVWP irrigation systems for forage production competitive at forage market prices ranging between 150 and $200 \$$ /tonne DM. The spatial distribution of the selected optimal locations is shown in Fig. 9 as a function of two market forage prices: 300 and $500 \$ /$ tonne DM. At 300 \$/tonne DM, 21 locations over the suitable 512 are selected, whereas 190 are selected at $500 \$ /$ tonne DM. Most of the selected locations are distributed in Tibet, Inner Mongolia, and Qinghai. In general, the selected optimal locations are mainly marked out by low depth of the groundwater resources and IWR, and high increased NPP through irrigation. The easy accessibility to groundwater resources and the contained IWR lower down the ICC of the PVWP irrigation systems. On the other hand, the high NPP achieved through irrigation raises the system revenues.

Fig. 10 shows a sensitivity analysis on how the most significant model parameters, such as carbon offsets, forage management costs, PV module price, increased forage yield, and potential carbon sequestration, can affect the selection of the optimal locations and accordingly the increased forage supply. The influence of each parameter is studied with a percentage of variation ranging 


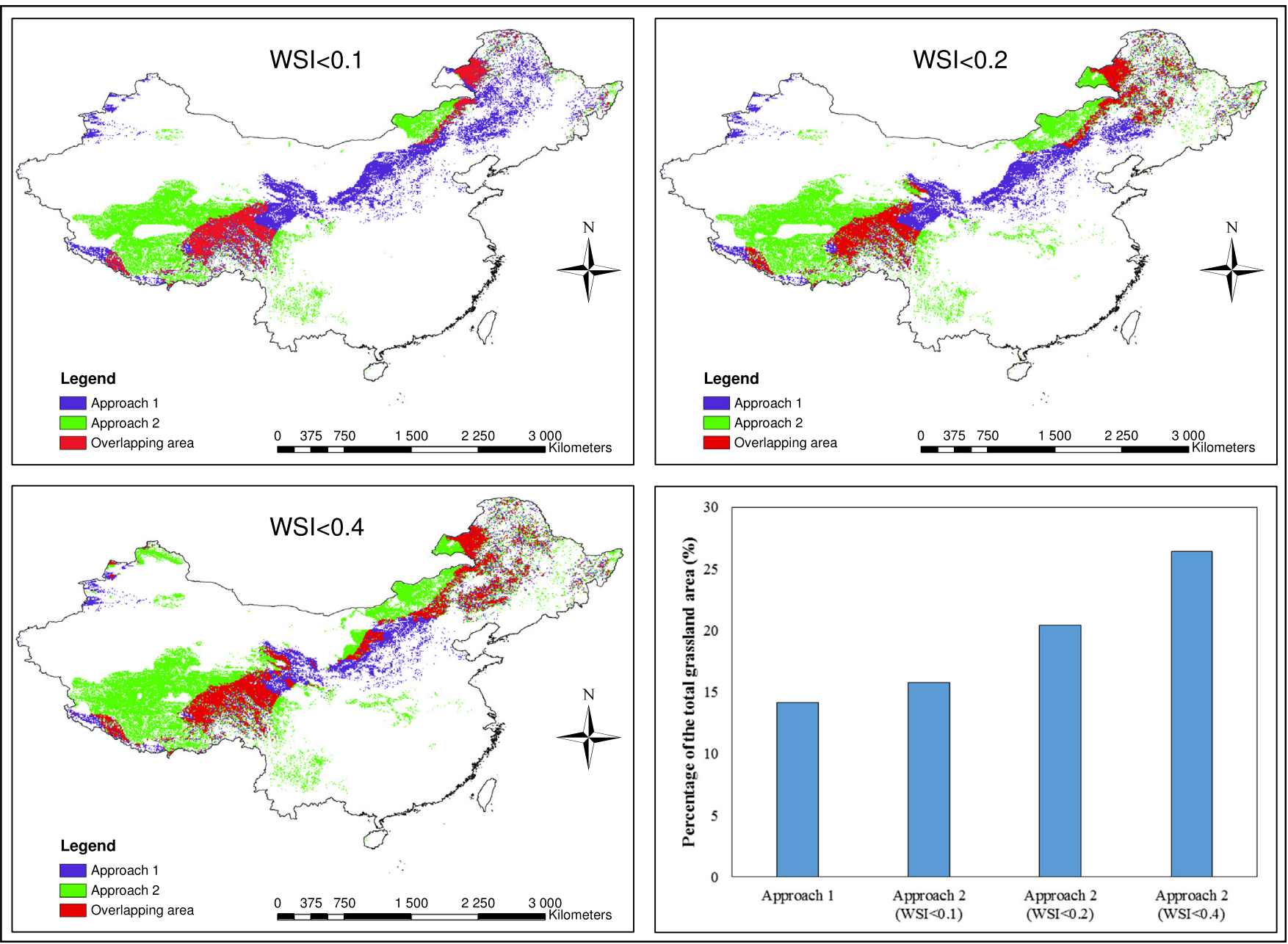

Fig. 7. Maps of the suitable areas for implementing PVWP irrigation systems.

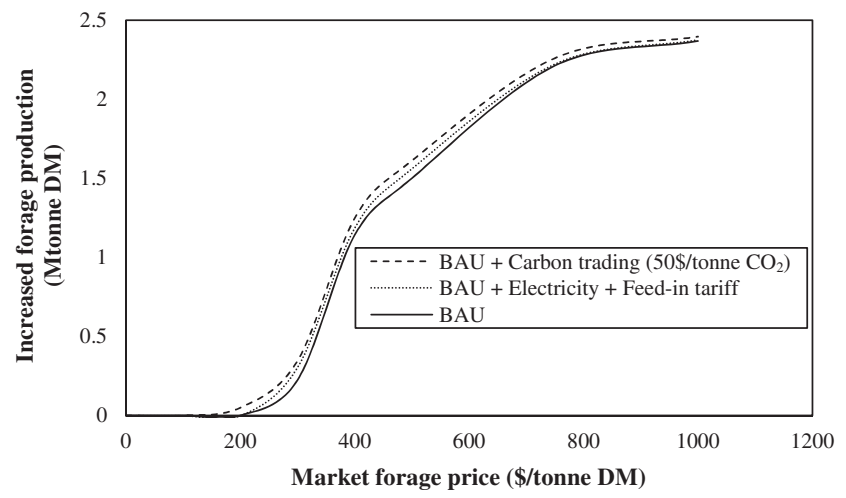

Fig. 8. PVWP increased forage production as a function of the market forage price for different studied scenarios.

between $\pm 50 \%$, except for the forage management cost and increased forage yield ranging between $\pm 25 \%$.

The forage management costs and the increased forage yield have the strongest impacts on the increased forage production and thus on the optimization process. This result highlights the importance of decreasing the agricultural management practices to lower the forage management costs and make the forage production more competitive. A $25 \%$ decrease in the forage management costs can increase the forage production, due to the larger number of optimal location selected, of $250 \%$. At the same time, it also shows how the assessment of the increased forage yield due to irrigation is a crucial aspect to determine the profitability of implementing PVWP irrigation technology. An increase of $25 \%$ in the forage yield results in a $300 \%$ increase in the forage production using PVWP irrigation systems. The price set for $\mathrm{CO}_{2}$ emissions and the amount of carbon sequestration, as well as the other sensitive parameters, have a significant effect on the optimization process but almost not comparable with the first two parameters analyzed.

Based on the assumption made, the net mitigation impact on climate change as a function of the market forage price is depicted in Fig. 11. The depicted net mitigation is the resulting balance between $\mathrm{CO}_{2}$ emissions due to transportation, $\mathrm{CO}_{2}$ emission reductions achievable through the power production from PV technology, and $\mathrm{CO}_{2}$ sequestration.

Similarly to the potential PVWP forage production, increasing the market forage price, the number of locations selected as optimal increases as well as the potential in $\mathrm{CO}_{2}$ emission reductions from PV power and sequestration. The $\mathrm{CO}_{2}$ emission reduction potential is very high, especially due to carbon sequestration. Nevertheless, it is interesting to note that considering the $\mathrm{CO}_{2}$ emissions due to transportation, the overall $\mathrm{CO}_{2}$ emissions balance is negative, especially at high market forage price. By increasing the market forage price, the number of locations selected increases and accordingly the amount of forage and transportation distances. This result shows that the forage production using PVWP irrigation 

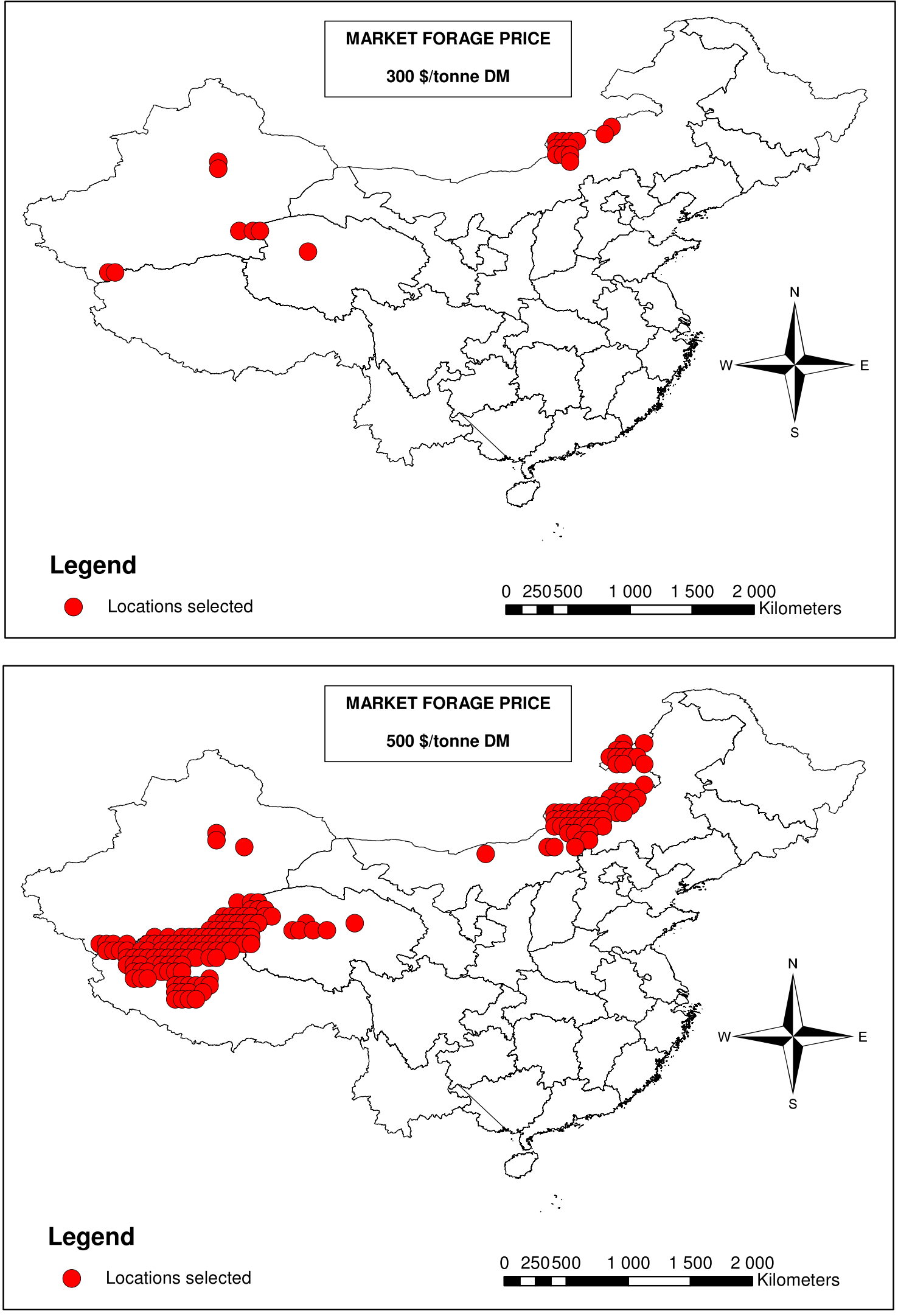

Fig. 9. Spatial distribution of the selected optimal locations depending on the market forage prices: 300 (upper) and 500 (lower) \$/tonne DM. 


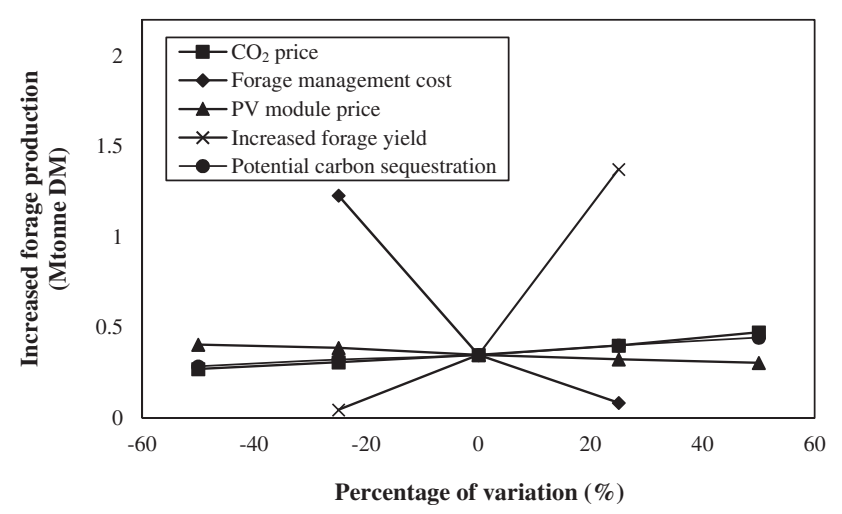

Fig. 10. Sensitivity analysis of parameters affecting the increased forage yield.

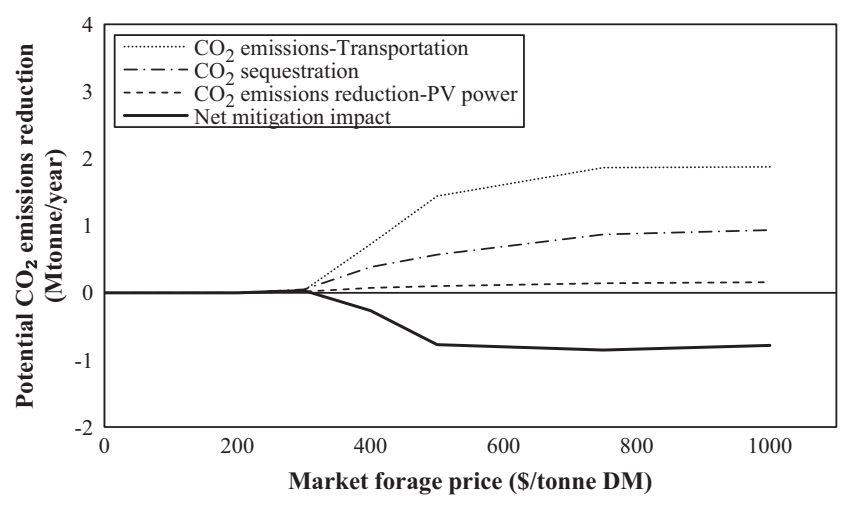

Fig. 11. Net mitigation impact as a function of the market forage price.

systems can have significant negative environmental impacts if the forage production is not locally used.

\subsection{Limitations}

This study is restricted to the grassland areas in China. Therefore, farmland areas were not taken into consideration in the forage supply chain. Future works will also be focused on farmland areas.

For solving the optimization model, China was covered with a grid of cells with a half-degree (equals $50 \mathrm{~km} \times 50 \mathrm{~km}$ at the Equator) spatial resolution for computational time issues. Thus, the original maps spatial resolution was aggregated to half-degree resolution.

To avoid high pressure on the available water resources due to irrigation, only $1 \%$ of each cell grid was assumed as forage supply area. A more specific value could be obtained considering the grid cells hydrologic balance, and accordingly the water resources availability and irrigation volumes. Nevertheless, this hydrologic analysis is beyond the scope of this article and can be considered as a starting point for future studies.

Due to the lack of spatial data, water quality issues, such as water salinity or water pollution from chemicals or heavy metals, were not addressed in this study to identify the suitable grassland areas for irrigation. The water salinity issue was partially tackled considering the leaching requirement LR in designing of the PVWP irrigation systems as discussed in Section 2.2.1.

Using PVWP systems for grassland restoration and conservation is eligible to subsidy and incentive scheme for grassland ecology protection [55]. The current available subsidies for grassland improvement were not taken into consideration in this study, since it is the objective of parallel studies on the development of new business models for implementing PVWP systems for grassland irrigation [56].

\section{Conclusions}

PVWP systems represent a renewable energy-based solution to support the sustainable development of the pastoral and agricultural sectors in China. The potentials of PVWP systems for grassland conservation and augmentation of its productivity are substantial. However, the optimal locations are sensitive to several environmental and economic parameters such as increased forage potential yield, forage management costs, forage water requirements, ground water depth, forage price and $\mathrm{CO}_{2}$ price that need to be carefully considered. The potential mitigation impact on climate change is also very high, especially due to the carbon sequestration. Nevertheless, if the forage production is not locally utilized, the $\mathrm{CO}_{2}$ emissions due to forage transportation can negatively affect the net carbon emission balance.

The developed methodology, i.e. the combination of GIS combined with modeling, optimization and renewable energy technology, can be applied in many countries and regions in the world.

\section{Acknowledgements}

The authors are grateful to the Swedish Research Council for Environment, Agricultural Sciences and Spatial Planning (FORMAS) for the financial support of one of the authors, P.E. Campana for the participation to the 2014 Young Scientist Summer Program (YSSP) at the International Institute for Applied Systems Analysis (IIASA). Previous studies on PVWP were supported by The Swedish International Development Cooperation Agency (Sida) and Swedish Agency for Economic and Regional Growth (Tillväxtverket). This study was also supported by the Projects of International Cooperation and Exchanges NSFC (41161140353), the National Natural Science Foundation of China (91325302, 91425303), the Beijing Natural Science Foundation Grant (8151002), and the Fundamental Research Funds for the Central Universities (TD-JC-2013-2). The authors would like to thank the two anonymous reviewers who provided useful feed-back to improve the quality of the study. The authors are also grateful to Dr. Patrik Klintenberg for his support.

\section{References}

[1] Akiyama T, Kawamura K. Grassland degradation in China, methods of monitoring, management and restoration. Jpn Soc Grassland Sci 2006. ISSN1744-6961.

[2] Yan J, Wang H, Gao Z. Qinghai pasture conservation using solar photovoltaic (PV)-driven irrigation. Asian Development Bank, Final Report ADB RSC-C91300 (PRC); 2010.

[3] Yu Y, Liu J, Wang H, Liu M. Assess the potential of solar irrigation systems for sustaining pasture lands in arid regions - a case study in Northwestern China. Appl Energy 2011;88:3176-82.

[4] Xu H, Liu J, Qin D, Gao X, Yan J. Feasibility analysis of solar irrigation system for pastures conservation in a demonstration area in Inner Mongolia. Appl Energy 2013;112:697-702.

[5] Yan J, Gao Z, Campana PE, Olsson A, Liu J, Yu G, et al. Demonstration and scaleup of photovoltaic water pumping for the conservation of grassland and farmland in China. SIDA report. <http://www.ae-innovation.org/CMS/index. php>; 2013 [accessed 25.07.15].

[6] Campana PE, Olsson A, Li H, Yan J. An economic analysis of photovoltaic water pumping irrigation system. Int J Green Energy 2015 [in press].

[7] BeWhere. <http://www.iiasa.ac.at/web/home/research/modelsData/Bewhere/ BEWHERE1.en.html> [accessed 25.11.14].

[8] Leduc S, Wetterlund E, Dotzauer E, Kindermann G. CHP or biofuel production in Europe? Energy Procedia 2012:20:40-9.

[9] Leduc S, Starfelt F, Dotzauer E, Kindermann G, McCallum I, Obersteiner M, et al. Optimal location of lignocellulosic ethanol refineries with polygeneration in Sweden. Energy 2010;35:2709-16.

[10] Leduc S, Lundgren J, Franklin O, Dotzauer E. Location of a biomass based methanol production plant: a dynamic problem in northern Sweden. Appl Energy 2010;87:68-75. 
[11] DIVA-GIS. <http://www.diva-gis.org/> [accessed 25.07.15].

[12] WorldClim. <http://www.worldclim.org/> [accessed 25.07.15].

[13] Hijmans RJ, Cameron SE, Parra JL, Jones PG, Jarvis A. Very high resolution interpolated climate surfaces for global land areas. Int J Climatol 2005;25:1965-78.

[14] Trabucco A, Zomer RJ. Global aridity index (Global-Aridity) and global potential evapo-transpiration (Global-PET) geospatial database, 2009. CGIAR consortium for spatial information. Published online, available from the CGIAR-CSI GeoPortal at: <http://www.csi.cgiar.org/> [accessed 25.11.14]

[15] Vörösmarty CJ, Green P, Salisbury J, Lammers RB. Global water resources: vulnerability from climate change and population growth. Science 2000:289:284.

[16] Meteonorm. <http://meteonorm.com/> [accessed 25.07.15].

[17] Olsson A, Campana PE, Lind M, Yan J. Potential for carbon sequestration and mitigation of climate change by irrigation of grasslands. Appl Energy 2014; $136: 1145-54$

[18] Wetterlund E, Leduc S, Dotzauer E, Kindermann G. Optimal localisation of biofuel production on a European scale. Energy 2012;41:462-72.

[19] Campana PE, Li H, Yan J. Techno-economic feasibility of the irrigation system for the grassland and farmland conservation in China: photovoltaic vs. wind power water pumping. Energy Convers Manage 2015;103:311-20.

[20] FAO-GeoNetwork. <http://www.fao.org/geonetwork/srv/en/metadata.show? id $=7416 \&$ currTab $=$ simple $>$ [accessed 25.07.15].

[21] Allen RG, Pereira LS, Raes D, Smith M. Crop evapotranspiration. Guidelines for computing crop water requirements. FAO; 1998.

[22] Campana PE, Li H, Yan J. Dynamic modeling of a PV pumping system with special consideration on water demand. Appl Energy 2013;112:635-45.

[23] Tanasijevic L, Todorovic M, Pereira LS, Pizzigalli C, Lionello P. Impacts of climate change on olive crop evapotranspiration and irrigation requirements in the Mediterranean region. Agric Water Manage 2014;144:54-68.

[24] Corwin DL, Rhoades JD, Simunek J. Leaching requirement for soil salinity control: steady-state versus transient models. Agric Water Manage 2007;90:165-80.

[25] Frasconi M. PV solar water pumping technology and system for the conservation of grassland in China: project and analysis of sprinkler and drip irrigation systems. Mälardalen University, DiVA: diva2:546765; 2012.

[26] GLOBAL WATER SCARCITY INFORMATION SERVICE (GLOWASIS). <http://glowasis.eu/> [accessed 25.07.15].

[27] Fan Y, Li H, Miguez-Macho G. Global patterns of groundwater table depth. Science 2013;339:940.

[28] OpenEI- Solar and Wind Energy Resource Assessment (SWERA). <http://en. openei.org/wiki/SWERA/Data> [accessed 25.07.15].

[29] Markvart T. Solar electricity. Wiley; 2009.

[30] Khatib T. Design of photovoltaic water pumping systems at minimum cost for Palestine: a review. J Appl Sci 2010;10(22):2773-84.

[31] Skoplaki E, Palyvos JA. On the temperature dependence of photovoltaic module electrical performance. A review of efficiency/power correlations. Sol Energy 2009;83:614-24.

[32] Solartech. <http://www.solartech.cn> [accessed 25.07.15].

[33] Campana PE, Zhu Y, Brugiati E, Li H, Yan J. PV water pumping for irrigation equipped with a novel control system for water savings. Energy Procedia 2014;61:949-52.

[34] Duffie JA, Beckman WA. Solar engineering of thermal processes. Wiley; 2006.

[35] Sun H, Zi Q, Wang Y, Yao Q, Si J. China's solar photovoltaic industry development: the status quo, problems and approaches. Appl Energy 2014;118:221-30.

[36] Olsson A, Campana PE, Lind M, Yan J. PV water pumping for carbon sequestration in dry land agriculture. Energy Convers Manage 2015;102:169-79.
[37] UNFCCC (United Nations Framework Convention on Climate Change). Clean developing mechanism, TOOL07 methodological tool: tool to calculate the emission factor for an electricity system Version 04.0; 2014.

[38] Chinese DNA. 2014 年中国区域电网基准线排放因子. <www.ccchina.gov.cn/ ashx/ReadFile.ashx?Id=6630>; 2014 [Chinese] [accessed 01.06.15].

[39] Ozdogan M. Exploring the potential contribution of irrigation to global agricultural primary productivity. Global Biogeochem Cycles 2011;25: GB3016. http://dx.doi.org/10.1029/2009GB003720.

[40] Vadrevu K, Lasko K. Fire regimes and potential bioenergy loss from agricultural lands in the Indo-Gangetic Plains. J Environ Manage 2015;148:10-20.

[41] Qin Z, Zhuang Q, Chen M. Impacts of land use change due to biofuel crops on carbon balance, bioenergy production, and agricultural yield, in the conterminous United States. GCB Bioenergy 2012;4:277-88.

[42] Prince SD, Haskett J, Steininger M, Strand H, Wright R. Net primary production of U.S. Midwest croplands from agricultural harvest yield data. Ecol Appl 2001:11(4):1194-205.

[43] Chen K. Why sales of U.S. alfalfa to South China are poised to grow. USDA Foreign Agricultural Service; 2009.

[44] IPCC (Intergovernmental Panel on Climate Change). Good practice guidance for land use, land-use change and forestry 2003. IPCC/IGES: Hayama, Japan; 2003.

[45] Batjes NH. IPCC default soil classes derived from the Harmonized World Soil Data Base (ver. 1.1). <http://www.isric.org/data/ipcc-default-soil-classesderived-harmonized-world-soil-data-base-ver-11>; 2010 [accessed 01.06.15].

[46] Wang S, Wilkes A, Zhang Z, Chang X, Lang R, Wang Y, et al. Management and land use change effects on soil carbon in northern China's grasslands: a synthesis. Agric Ecosyst Environ 2011;142:329-40.

[47] FAO. <http://www.fao.org/ag/againfo/resources/en/glw/GLW_dens.html> [accessed 25.07.15].

[48] Pulina G, Avondo M, Molle G, Dias Francesconi AH, Atzori AS, Cannas A. Models for estimating feed intake in small ruminants. Revista Brasileira de Zootecnia 2013;42(9):675-90.

[49] Pandey GS, Voskuil GCJ. Manual on improved feeding of dairy cattle by smallholder farmers. <http://www.gartzambia.org/files/Download/Dairy\% 20manual\%20-\%20Feeding.pdf>; 2001 [accessed 01.06.15].

[50] Sokhansanj S, Mani S, Turhollow A, Kumar A, Bransby D, Lynd L, et al. Largescale production, harvest and logistics of switchgrass (Panicum virgatum L.) current technology and envisioning a mature technology. Biofuels, Bioprod Bioref 2009;3:124-41.

[51] CEFIC. Guidelines for measuring and managing $\mathrm{CO}_{2}$ emission from freight transport operations. <http://www.cefic.org/Documents/IndustrySupport/ Transport-and-Logistics/Best\%20Practice\%20Guidelines\%20-\%20General\%20 Guidelines/Cefic-ECTA\%20Guidelines\%20for\%20measuring\%20and\%20managing\% 20CO2\%20emissions\%20from\%20transport\%20operations\%20Final\%2030.03. 2011.pdf >; 2011 [accessed 01.08.15].

[52] Herrero M, Havlík P, Valin H, Notenbaert A, Rufino MC, Thorntond PK, et al. Biomass use, production, feed efficiencies, and greenhouse gas emissions from global livestock systems. <www.pnas.org/lookup/suppl/doi:10.1073/pnas. 1308149110/-/DCSupplemental>; 2013 [accessed 01.06.15].

[53] Cnagri. <http://en.cnagri.com/> [accessed 25.11.14].

[54] The Economist. The drying of the West-Drought is forcing westerners to consider wasting less water. <http://www.economist.com/news/unitedstates/21596955-drought-forcing-westerners-consider-wasting-less-waterdrying-west> [accessed 25.11.14].

[55] Ministry of Agriculture of the Peoplés Republic of China. 2012 policy measures to support increase in grain output and farmers' income (Part II). <www. ccchina.gov.cn/ashx/ReadFile.ashx?Id=6630>; 2013 [accessed 14.12.15].

[56] Zhang C, Yan J. Business model innovation on the photovoltaic water pumping systems for grassland and farmland conservation in China. Energy Procedia 2014;61:1483-6. 